\title{
Ferromagnetic Exchange in Two Dicopper(II) Complexes Using a $\mu$-Alkoxo- $\mu$-7-azaindolate Bridge
}

\author{
Yi-Chian Chou, ${ }^{\dagger}$ Shu-Fei Huang, ${ }^{\dagger}$ Rajesh Koner, ${ }^{\ddagger}$ Gene-Hsiang Lee, ${ }^{\S}$ Yu Wang, ${ }^{\S}$ \\ Sasankasekhar Mohanta, ${ }^{*} \neq$ and Ho-Hsiang Wei ${ }^{*, \dagger}$ \\ Department of Chemistry, Tamkang University, Tamsui, Taiwan 25137, Department of Chemistry, \\ University of Calcutta, 92 A. P. C. Ray Road, Kolkata 700 009, India, and Instrumental Center, \\ College of Science, National Taiwan University, Taipei, Taiwan
}

Received November 15, 2003

Syntheses, structures, and magnetic properties of two heterobridged $\mu$-alkoxo- $\mu$-7-azaindolate dicopper(II) complexes, $\left[\mathrm{Cu}_{2}{ }_{2}(\mathrm{~L}-\mathrm{F})(\mu\right.$ $\left.\left.\mathrm{C}_{7} \mathrm{H}_{5} \mathrm{~N}_{2}\right)\right](1)$ and $\left[\mathrm{Cu}_{2}{ }_{2}(\mathrm{~L}-\mathrm{H})\left(u-\mathrm{C}_{7} \mathrm{H}_{5} \mathrm{~N}_{2}\right)\right] \cdot \mathrm{CH}_{3} \mathrm{OH}(2)\left(\mathrm{H}_{3} \mathrm{~L}-\mathrm{F}=1,3-\right.$ bis(3-fluorosalicylideneamino)-2-propanol; $\mathrm{H}_{3} \mathrm{~L}-\mathrm{H}=$ 1,3-bis(salicylideneamino)-2-propanol) have been reported. Aside from being a new type of heterobridged complex, 1 and 2 exhibit ferromagnetic interaction $\left(2 \mathrm{~J}=52 \mathrm{~cm}^{-1}\right.$ for 1 and $33.4 \mathrm{~cm}^{-1}$ for 2) despite orbital complementarity (7-azaindolate $\mathrm{HOMO}$ is antisymmetric).

The prediction of sign and magnitude of magnetic exchange integrals as a function of structural parameters and vice versa as well as the design of new exchange-coupled systems are some of the major challenges in magnetochemistry. ${ }^{1}$ Since most of the reported exchange-coupled systems are antiferromagnetic in nature, ${ }^{2}$ designed synthesis of compounds that exhibit ferromagnetic interactions still remains as a challenging task. ${ }^{\mathrm{a}, \mathrm{k}}$

* To whom correspondence should be addressed. E-mail: s_mohanta@ hotmail.com (S.M.); tkwei@mail.tku.edu.tw (H.-H.W.). Fax: 91-3323519755 (S.M.); 886-2-26209924 (H.-H.W.).

$\dagger$ Tamkang University.

$\doteqdot$ University of Calcutta.

$\S$ National Taiwan University.

(1) (a) Kahn, O. Molecular Magnetism; VCH Publications: New York, 1993 and references therein. (b) Magneto-Structural Correlations in Exchange Coupled Systems; Willett, R. D., Gatteschi, D., Kahn, O. Eds.; Kluwer Academic Publishers: Dordrecht, The Netherlands, 1985 and references therein. (c) Charlot, M. F.; Jeannin, S.; Jeannin, Y.; Kahn, O.; Lucrece-Abaul, J. Inorg. Chem. 1979, 18, 1675. (d) Niemann, A.; Bossek, U.; Wieghardt, K.; Butzlaff, C.; Trautwein, A. X.; Nuber, B.; Angew. Chem., Int. Ed. Engl. 1992, 31, 311. (e) Bürger, K.-S.; Chaudhuri, P.; Wieghardt, K. J. Chem. Soc., Dalton Trans. 1996, 247. (f) Chung, Y.-H.; Wei, H.-H.; Liu, Y.-H.; Lee, G.-H.; Wang, Y. J. Chem. Soc., Dalton Trans. 1997, 2825. (g) Thompson, L. K.; Mandal, S. K.; Tandon, S. S.; Bridson, J. N.; Park, M. K. Inorg. Chem. 1996, 35, 3117. (h) Gorun, S. M.; Lippard, S. J. Inorg. Chem. 1991, 30, 1625. (i) Merz, L.; Haase, W. J. Chem. Soc., Dalton Trans. 1980 , 875. (j) Ribas, J.; Escuer, A.; Monfort, M.; Vicente, R.; Cortés, R.; Lezama, L.; Rojo, T. Coord. Chem. Rev. 1999, 193-195 1027. (k) Mohanta, S.; Nanda, K. K.; Thompson, L. K.; Flörke, U.; Nag, K. Inorg. Chem. 1998, 37, 1465.

(2) Chen, C. T.; Suslick, K. S. Coord. Chem. Rev. 1993, 128, 293.

10.1021/ic035322t CCC: $\$ 27.50$ C 2004 American Chemical Society Published on Web 04/03/2004
Heterobridged $\mu$-hydroxo/alkoxo- $\mu$-X $\left(\mathrm{X}=\mathrm{N}_{3}{ }^{-}, \mathrm{NO}_{2}{ }^{-}\right.$, pyrazolate, carboxylate, etc.) compounds can be considered as a special class of exchange-coupled systems where the magnetic properties are more dependent on the second bridging ligand $(\mathrm{X})$; e.g., they are strongly antiferromagnetic for $\mathrm{X}=\mathrm{N}_{3}{ }^{-}$, moderately antiferromagnetic for $\mathrm{X}=\mathrm{NO}_{2}{ }^{-}$, weakly to strongly antiferromagnetic for $\mathrm{X}=$ pyrazolate, and weakly antiferromagnetic to weakly ferromagnetic for $\mathrm{X}=\mathrm{RCO}_{2}^{-}{ }^{-1 \mathrm{a}, \mathrm{e}, 3}$ Evidently, most of the $\mu$-hydroxo/alkoxo$\mu$-X systems are antiferromagnetically coupled; ferromagnetic interaction has been observed in only a few $\mu$-hydroxo/ alkoxo- $\mu$-carboxylato compounds. ${ }^{3 \mathrm{c}, \mathrm{d}, \mathrm{k}}$ The apparent anomaly in magnetic behavior of this type of complexes, however, has been explained in the Hoffmann theoretical model by introducing the concept of complementarity and countercomplementarity of the HOMO of the second bridging ligand to enhance or reduce the energy gap between the symmetric and antisymmetric combinations of the magnetic orbitals. ${ }^{1 \mathrm{a}, 3 \mathrm{a}, \mathrm{d}, \mathrm{g}}$

In order to develop new types of heterobridged $\mu$-alkoxo$\mu$-X compounds, we have used 7-azaindolate as the second bridging ligand and isolated two dicopper(II) complexes, $\left[\mathrm{Cu}_{2}{ }_{2}(\mathrm{~L}-\mathrm{F})\left(\mu-\mathrm{C}_{7} \mathrm{H}_{5} \mathrm{~N}_{2}\right)\right](\mathbf{1})$ and $\left[\mathrm{Cu}^{\mathrm{II}}(\mathrm{L}-\mathrm{H})\left(\mu-\mathrm{C}_{7} \mathrm{H}_{5} \mathrm{~N}_{2}\right)\right] \cdot$ $\mathrm{CH}_{3} \mathrm{OH}(2)\left(\mathrm{H}_{3} \mathrm{~L}-\mathrm{F}=1,3\right.$-bis(3-fluorosalicylideneamino)2-propanol; $\mathrm{H}_{3} \mathrm{~L}-\mathrm{H}=1,3$-bis(salicylideneamino)-2-propanol). We have been particularly interested to use 7-azaindolate as a bridging moiety because it was anticipated that

(3) (a) McKee, V.; Zvagulis, M.; Dagdigian, J. V.; Patch, M. G.; Reed, C. A. J. Am. Chem. Soc. 1984, 106, 4765. (b) McKee, V.; Zvagulis, M.; Reed, C. A. Inorg. Chem. 1985, 24, 2914. (c) Mazurek, W.; Kennedy, B. J.; Murray, K. S.; O'Connor, M. J.; Rodgers, J. R.; Snow, M. R.; Wedd, A. G.; Zwack, P. R. Inorg. Chem. 1985, 24, 3258. (d) Nishida, Y.; Kida, S. Inorg. Chem. 1988, 27, 447. (e) Nie, H.; Aubin, S. M. J.; Mashuta, M. S.; Porter, R. A.; Richardson, J. F.; Hendrickson, D. N.; Buchanan, R. M. Inorg. Chem. 1996, 35, 3325. (f) Davis, W. M.; Lippard, S. J. Inorg. Chem. 1985, 24, 3688. (g) Nishida, Y.; Kida, S. J. Chem. Soc., Dalton Trans. 1986, 2633. (h) Meenakumari, S. Tiwari, S. K.; Chakravarty, A. R. J. Chem. Soc., Dalton Trans. 1993, 2175. (i) Kawata, T.; Yamanaka, M.; Ohba, S.; Nishida, Y.; Nagamatsu, M.; Tokii, T.; Kato, M.; Steward, O. W. Bull. Chem. Soc. Jpn. 1992, 65, 2739. (j) Boxwell, C. J.; Bhalla, R.; Cronin, L.; Turner, S. S.; Walton, P. H. J. Chem. Soc., Dalton Trans. 1998, 2449. (k) Christou, G.; Perlepes, S. P.; Libby, E.; Folting, K.; Huffman, J. C.; Webb, R. J.; Hendrickson, D. N. Inorg. Chem. 1990, 29, 3657.

Inorganic Chemistry, Vol. 43, No. 9, 20042759 


\section{COMMUNICATION}

its introduction will induce considerable twist in the complex molecules to bring about significant changes in their exchange interactions.

The ligands $\mathrm{H}_{3} \mathrm{~L}-\mathrm{F}$ and $\mathrm{H}_{3} \mathrm{~L}-\mathrm{H}$ were isolated as yellow crystalline compounds through the condensation of 1,3diamino-2-propanol with 3-fluorosalicylaldehyde and salicylaldehyde, respectively. Complexes $\mathbf{1}$ and $\mathbf{2}$ were obtained ${ }^{4}$ by reacting $\mathrm{H}_{3} \mathrm{~L}-\mathrm{F}$ or $\mathrm{H}_{3} \mathrm{~L}-\mathrm{H}$ with $\mathrm{Cu}\left(\mathrm{ClO}_{4}\right)_{2} \cdot 6 \mathrm{H}_{2} \mathrm{O}$, 7-azaindole, and triethylamine. The X-ray crystal structures ${ }^{5}$ of the two complexes are found to be similar. The structure of 1 (Figure 1) shows that the two metal centers are doubly bridged by the alkoxo oxygen and the 7-azaindolate anion. In addition, each of the metal centers is coordinated to one imine nitrogen and one phenolate oxygen provided by the ligand $[\mathrm{L}-\mathrm{F}]^{2-}$. The deviations of the donor atoms $(0.21 \AA$ (average) for $\mathrm{Cu}(1)$ and $0.08 \AA$ (average) for $\mathrm{Cu}(2))$ and the metal centers $(0.004 \AA$ for $\mathrm{Cu}(1)$ and $0.07 \AA$ for $\mathrm{Cu}(2))$ from the coordination planes and also the range of the cisoid $\left(83.4(3)^{\circ}-94.2(3)^{\circ}\right.$ for $\mathrm{Cu}(1)$ and $84.5(2)^{\circ}-95.4(2)^{\circ}$ for $\mathrm{Cu}(2))$ and transoid $\left(164.8(3)^{\circ}\right.$ and $170.1(4)^{\circ}$ for $\mathrm{Cu}(1)$, and $166.3(2)^{\circ}$ and $167.7(2)^{\circ}$ for $\left.\mathrm{Cu}(2)\right)$ angles indicate that the coordination geometry of the metal ions can be approximated as square planar. It should be noted that the bridging moiety in $\mathbf{1}$ is appreciably twisted; the dihedral angle $(\delta)$ between the best coordination planes is $112.8^{\circ}\left(\delta=180^{\circ}\right.$ for coplanarity). The twisting is further indicated by the smaller $\mathrm{Cu}(1)-\mathrm{O}(1)-\mathrm{Cu}(2)$ bridge angle $\left(112.0(2)^{\circ}\right)$ and the shorter $\mathrm{Cu}(1) \cdots \mathrm{Cu}(2)$ separation (3.239 (1) $\AA$ ).

The molecular structure of 2 (Figure S1, Supporting Information) is essentially similar to that of $\mathbf{1}$, except that the asymmetric unit of $\mathbf{2}$ contains two independent dimers (I and II) having structural parameters that are almost the

(4) To a stirred methanol solution $(30 \mathrm{~mL})$ containing $\mathrm{H}_{3} \mathrm{~L}-\mathrm{H}(0.298 \mathrm{~g}$, $1 \mathrm{mmol})$ were successively added methanol solution $(10 \mathrm{~mL})$ of copper(II) perchlorate hexahydrate $(0.74 \mathrm{~g}, 2 \mathrm{mmol})$, methanol solution $(10 \mathrm{~mL})$ of 7 -azaindole $(0.118 \mathrm{~g}, 1 \mathrm{mmol})$, and triethylamine $(0.52 \mathrm{~g}$, $\sim 5 \mathrm{mmol})$. After a few minutes, a green mass was precipitated. The stirring was continued for $1 \mathrm{~h}$, and the green compound was collected by filtration. Recrystallization from a dimethylformamide-methanol mixture afforded the green crystalline compound, $\left[\mathrm{Cu}^{\mathrm{II}} 2(\mathrm{~L}-\mathrm{H})(\mu\right.$ $\left.\left.\mathrm{C}_{7} \mathrm{H}_{5} \mathrm{~N}_{2}\right)\right] \cdot \mathrm{CH}_{3} \mathrm{OH}(2)$. Yield: $0.2 \mathrm{~g}(35 \%)$. Anal. Calcd for $\mathrm{C}_{25} \mathrm{H}_{24} \mathrm{~N}_{4} \mathrm{O}_{4}$ $\mathrm{Cu}_{2}$ : C, 52.53, H, 4.23, N, 9.80. Found: C, 52.31, H, 4.34, N, 9.64. IR(KBr): $1634 \mathrm{~cm}^{-1}\left(v_{\mathrm{C}=\mathrm{N}}\right)$. Single crystals of 2 were prepared by diffusing a methanol-acetontrile (2:1) mixture into a dimethylformamide solution of the green crystalline compound. The compound $\left[\mathrm{Cu}^{\mathrm{II}}(\mathrm{L}-\mathrm{F})\left(\mu-\mathrm{C}_{7} \mathrm{H}_{5} \mathrm{~N}_{2}\right)\right]$ (1) was synthesized following the similar method as described for 2 , except using $\mathrm{H}_{3} \mathrm{~L}-\mathrm{F}$, instead of $\mathrm{H}_{3} \mathrm{~L}-\mathrm{H}$, and recrystallizing the green mass from dimethylformamide-acetontile mixture, instead of dimethylformamide-methanol. Yield: 40\%. Anal. Calcd for $\mathrm{C}_{24} \mathrm{H}_{18} \mathrm{~N}_{4} \mathrm{O}_{3} \mathrm{~F}_{2} \mathrm{Cu}_{2}$ : C, 50.08, H, 3.15, N, 9.73. Found: C, 49.86, H, 3.04, N, 9.84. IR(KBr): $1639 \mathrm{~cm}^{-1}\left(v_{\mathrm{C}=\mathrm{N}}\right)$. Single crystals of 1 were prepared by diffusing acetontrile into a dimethylformamide solution of the green crystalline compound.

(5) Crystallographic data for $\left[\mathrm{Cu}_{2}{ }_{2}(\mathrm{~L}-\mathrm{F})\left(\mu-\mathrm{C}_{7} \mathrm{H}_{5} \mathrm{~N}_{2}\right)\right]$ (1): $\mathrm{C}_{24} \mathrm{H}_{18} \mathrm{~N}_{4} \mathrm{O}_{3} \mathrm{~F}_{2}-$ $\mathrm{Cu}_{2}, \mathrm{fw}=575.50$, monoclinic, space group $P 2{ }_{1} / c, a=12.629(2) \AA$, $b=8.240(2) \AA, c=21.138(5) \AA, \beta=94.61(2)^{\circ}, V=2192.7(8) \AA^{3}$, $Z=4, \rho_{\text {calcd }}=1.743 \mathrm{~g} \mathrm{~cm}^{-3}, \mu=1.993 \mathrm{~mm}^{-1}$. The structure was solved by direct and Fourier methods and refined to R1 $(I>2 \sigma(I)$, 3847 unique reflections $)=0.0758$ and $w \mathrm{R} 2$ (all data $)=0.1801$. Crystallographic data for $\left[\mathrm{Cu}^{\mathrm{II}} 2(\mathrm{~L}-\mathrm{H})\left(\mu-\mathrm{C}_{7} \mathrm{H}_{5} \mathrm{~N}_{2}\right)\right] \cdot \mathrm{CH}_{3} \mathrm{OH}$ (2): $\mathrm{C}_{25} \mathrm{H}_{24} \mathrm{~N}_{4} \mathrm{O}_{4} \mathrm{Cu}_{2}$, fw $=571.56$, triclinic, space group $P 1, a=8.4259$ (5) $\AA, b=10.5013(7) \AA, c=13.0456(8) \AA, \alpha=86.839(1)^{\circ}, \beta=$ $80.266(1)^{\circ}, \gamma=89.923(1)^{\circ}, V=1135.93(12) \AA^{3}, Z=2, \rho_{\text {calcd }}=$ $1.671 \mathrm{~g} \mathrm{~cm}^{-3}, \mu=1.914 \mathrm{~mm}^{-1}$, R1 $(I>2 \sigma(I), 8158$ unique reflections $)=0.0697$ and $\mathrm{wR} 2($ all data $)=0.1801$. Data were collected on a Siemens Smart CCD and a Bruker Smart CCD diffractometer, respectively, for $\mathbf{1}$ and $\mathbf{2}$.

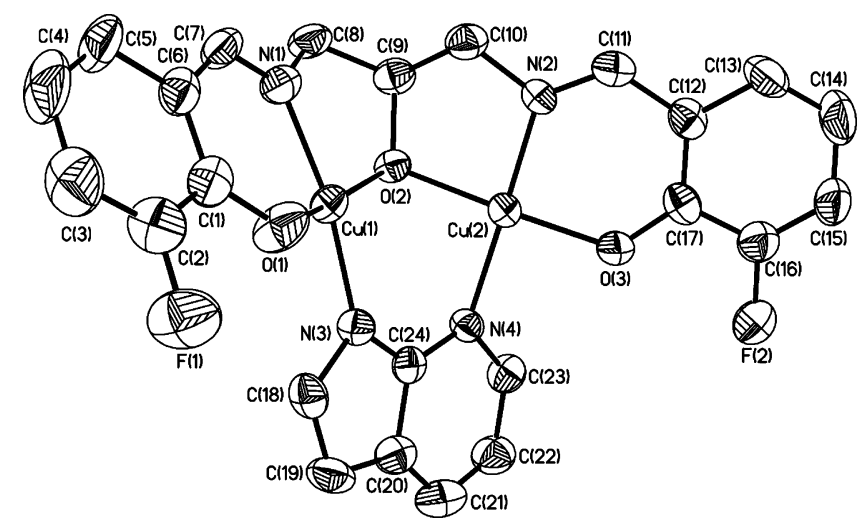

Figure 1. ORTEP representation (60\% thermal ellipsoids) of $\left[\mathrm{Cu}^{\mathrm{II}} 2(\mathrm{~L}-\mathrm{F})\left(\mu-\mathrm{C}_{7} \mathrm{H}_{5} \mathrm{~N}_{2}\right)\right](\mathbf{1})$ with atom level schemes. Selected bond lengths $(\AA)$ and angles $(\mathrm{deg}): \mathrm{Cu}(1)-\mathrm{O}(1)=1.908(5), \mathrm{Cu}(1)-\mathrm{O}(2)=1.958(5)$, $\mathrm{Cu}(1)-\mathrm{N}(1)=1.956(6), \mathrm{Cu}(1)-\mathrm{N}(3)=1.948(5), \mathrm{Cu}(2)-\mathrm{O}(2)=1.950(4)$, $\mathrm{Cu}(2)-\mathrm{O}(3)=1.918(5), \mathrm{Cu}(2)-\mathrm{N}(2)=1.938(5), \mathrm{Cu}(2)-\mathrm{N}(4)=1.971(5)$, $\mathrm{O}(1)-\mathrm{Cu}(1)-\mathrm{O}(2)=166.3(2), \mathrm{N}(1)-\mathrm{Cu}(1)-\mathrm{N}(3)=167.7(2), \mathrm{O}(1)-$ $\mathrm{Cu}(1)-\mathrm{N}(1)=92.0(2), \mathrm{O}(1)-\mathrm{Cu}(1)-\mathrm{N}(3)=90.9(2), \mathrm{O}(2)-\mathrm{Cu}(1)-\mathrm{N}(1)$ $=84.5(2), \mathrm{O}(2)-\mathrm{Cu}(1)-\mathrm{N}(3)=95.4(2), \mathrm{O}(2)-\mathrm{Cu}(2)-\mathrm{O}(3)=177.7(2)$, $\mathrm{N}(2)-\mathrm{Cu}(2)-\mathrm{N}(4)=170.4(2), \mathrm{O}(2)-\mathrm{Cu}(2)-\mathrm{N}(2)=85.1(2), \mathrm{O}(2)-$ $\mathrm{Cu}(2)-\mathrm{N}(4)=93.2(2), \mathrm{O}(3)-\mathrm{Cu}(2)-\mathrm{N}(2)=92.7(2), \mathrm{O}(3)-\mathrm{Cu}(2)-\mathrm{N}(4)$ $=89.2(2)$.

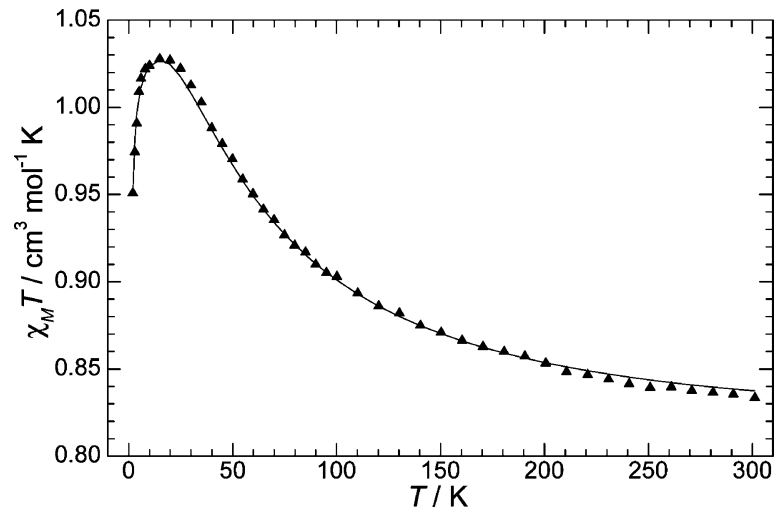

Figure 2. Experimental (ム) and calculated (-) $\chi_{\mathrm{M}} T$ vs $T$ plots for $\left[\mathrm{Cu}_{2}{ }_{2}(\mathrm{~L}-\mathrm{F})\left(\mu-\mathrm{C}_{7} \mathrm{H}_{5} \mathrm{~N}_{2}\right)\right](\mathbf{1})$.

same. As in 1, the bridging moieties are significantly twisted as reflected by the dihedral angles of $118.6^{\circ}$ (I) and $118.3^{\circ}$ (II) between the two coordination planes. The metal centers are separated by 3.288 (2) $\AA$ (I) and 3.286 (2) $\AA$ (II), and the corresponding $\mathrm{Cu}-\mathrm{O}-\mathrm{Cu}$ bridge angles are $114.4(3)^{\circ}$ (I) and $114.3(3)^{\circ}$ (II).

Variable-temperature $(2-300 \mathrm{~K})$ magnetic behavior in the form of $\chi_{\mathrm{M}} T$ versus $T$ plots of $\mathbf{1}$ and $\mathbf{2}$ is shown in Figures 2 and 3 , respectively. The profiles indicate the existence of intradimer ferromagnetic interaction in both the complexes. Taking into consideration the superexchange and zero-field effects of the triplet state $\left(\mathbf{H}=-2 J \mathbf{S}_{\mathbf{1}} \cdot \mathbf{S}_{\mathbf{2}}+D\left(\mathbf{S}_{\mathbf{Z}^{2}}-1{ }_{3} S_{\mathrm{T}^{-}}\right.\right.$ $\left.\left(S_{\mathrm{T}}+1\right)\right)$ and also the temperature independent paramagnetism (TIP), the susceptibility data can be simulated well with the equation $\chi_{\mathrm{M}}=\left[N \beta^{2} g^{2} / k T\right]\left[2 \mathrm{e}^{(2 J-D) / k T} /\left\{1+\mathrm{e}^{2 J / k T}+2 \mathrm{e}^{(2 J-D) / k T}\right\}\right]$ + TIP with the following set of converging parameters: 1 , $J=26 \mathrm{~cm}^{-1}, g=2.04,|D|=0.35 \mathrm{~cm}^{-1}$, and TIP $=40 \times$ $10^{-6} \mathrm{~cm}^{3} \mathrm{~mol}^{-1} ; 2, J=16.7 \mathrm{~cm}^{-1}, g=2.007,|D|=0.82$ $\mathrm{cm}^{-1}$, and TIP $=60 \times 10^{-6} \mathrm{~cm}^{3} \mathrm{~mol}^{-1}$ (see ref 6).

The magnetic behavior of $\mathbf{1}$ and $\mathbf{2}$, like other heterobridged complexes, in principle, should be explained by two-step perturbation process. ${ }^{1 \mathrm{a}, \mathrm{e}, 3}$ In the first step, overlaps of the 


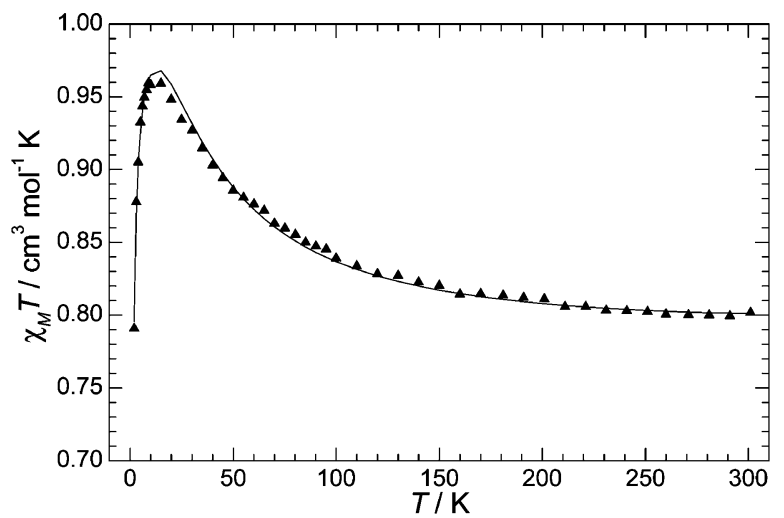

Figure 3. Experimental ( $\mathbf{\Delta})$ and calculated $(-) \chi_{\mathrm{M}} T$ vs $T$ plots for $\left[\mathrm{Cu}_{2}{ }_{2}(\mathrm{~L}-\mathrm{H})\left(\mu-\mathrm{C}_{7} \mathrm{H}_{5} \mathrm{~N}_{2}\right)\right] \cdot \mathrm{CH}_{3} \mathrm{OH}(\mathbf{2})$.

symmetric $\left(d_{s}\right)$ and antisymmetric $\left(d_{a}\right)$ combinations of the magnetic orbitals with the oxygen $\mathrm{p}$ orbitals take place to form new symmetric $\left(\mathrm{d}_{\mathrm{s}}{ }^{\prime}\right)$ and antisymmetric $\left(\mathrm{d}_{\mathrm{a}}{ }^{\prime}\right)$ combinations where $d_{s}{ }^{\prime}>d_{s}, d_{a}{ }^{\prime}>d_{a}$, and the relative energies of $\mathrm{d}_{\mathrm{s}}{ }^{\prime}$ and $\mathrm{d}_{\mathrm{a}}{ }^{\prime}$ depend on the structural parameters of the alkoxo bridging moeity. In the second step, $\mathrm{d}_{\mathrm{s}}{ }^{\prime}$ and $\mathrm{d}_{\mathrm{a}}{ }^{\prime}$ may interact with the HOMO of azaindolate to result in new combinations $\left(d_{s}{ }^{\prime \prime}\right.$ and $\left.d_{a}{ }^{\prime \prime}\right)$. Evidently, the relative energies of $d_{s}{ }^{\prime \prime}$ and $d_{a}{ }^{\prime \prime}$ are functions of both the first perturbation and the symmetry of the azaindolate HOMO. Density functional calculation shows that the lobes of the HOMO ( $\mathrm{A}^{\prime \prime}$ symmetric in $C_{1}$ point group) on two nitrogens are antisymmetric (Figure 4$){ }^{7}$ Clearly, due to the second perturbation (that is, orbital complementarity) the energy of the antisymmetric combination $\left(\mathrm{d}_{\mathrm{a}}{ }^{\prime \prime}\right)$ will increase, while the symmetric combination $\left(\mathrm{d}_{\mathrm{s}}{ }^{\prime \prime}\right)$ will remain practically unaffected. It may be noted that the accidental degeneracy of the two combinations $\left(\mathrm{d}_{\mathrm{s}}{ }^{\prime \prime}\right.$ and $\left.\mathrm{d}_{\mathrm{a}}{ }^{\prime \prime}\right)$ is an essential criterion for ferromagnetism. Since $E\left(\mathrm{~d}_{\mathrm{a}}{ }^{\prime \prime}\right)$ $>E\left(\mathrm{~d}_{\mathrm{a}}{ }^{\prime}\right)$ and $E\left(\mathrm{~d}_{\mathrm{s}}{ }^{\prime \prime}\right) \approx E\left(\mathrm{~d}_{\mathrm{s}}{ }^{\prime}\right)$, therefore, $\mathrm{d}_{\mathrm{a}}{ }^{\prime \prime}$ and $\mathrm{d}_{\mathrm{s}}{ }^{\prime \prime}$ will be degenerate only if $E\left(\mathrm{~d}_{\mathrm{a}}{ }^{\prime}\right)<E\left(\mathrm{~d}_{\mathrm{s}}{ }^{\prime}\right)$. Now, the problem is, how

(6) Although TIP, in principle, should be the same for the two complexes, the global minimizations take place with the reported values. However, if TIP is neglected, the fittings become slightly inferior in the 250$300 \mathrm{~K}$ range; the introduction of TIP has practically no effect on the other parameters.

(7) DFT calculation was performed by the Gaussian 03 program, Gaussian, Inc., Pittsburgh, PA, 2003. Method: Becke's three parameter hybrid functional using the LYP correlation functional (Becke, A. D. J. Chem. Phys. 1993, 98, 5648). Wave function: restricted closed shell. Basis set: split valence basis set 6-31G (Binning, R. C., Jr.; Curtiss, L. A. J. Comput. Chem. 1990, 11, 1206 and references therein). Structural parameters (atom, $x y z$ coordinates): C, $-2.37903,2.71996,-1.06640$; C, $-2.31482,4.07941,-0.87895 ; \mathrm{C},-1.18943,4.67241,-0.38632$; C, $-0.20217,2.47028,-0.44452 ; \mathrm{C},-0.09465,3.87240,-0.15411$ C, $1.23852,4.04638,0.36703 ; \mathrm{C}, 1.82552,2.80587,0.32957 ; \mathrm{H}$, $-3.18422,2.35514,-1.35893 ; \mathrm{H},-3.05184,4.60532,-1.09216 ; \mathrm{H}$, $-1.16204,5.58638,-0.21360 ; \mathrm{H}, 1.62240,4.83920,0.66792 ; \mathrm{H}$ $2.69426,2.63684,0.61385 ; \mathrm{N},-1.34165,1.87950,-0.85118 ; \mathrm{N}$, $0.97517,1.82991,-0.18201$.

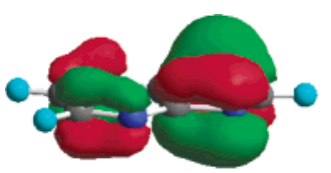

Figure 4. The azaindolate HOMO ( $\mathrm{A}^{\prime \prime}$ symmetric in $C_{1}$ point group). The blue atoms are nitrogens. This figure is based on a density functional calculation with the structural parameters of azaindolate moiety in complexe $1 .^{7}$

could this be? Smaller dihedral angle between the coordination planes as well as the out-of-plane $\pi$-bonding due to the pyramidal disposition of the alkoxo oxygen are two important factors to reduce the energy of the antisymmetric combination $\left(\mathrm{d}_{\mathrm{a}}{ }^{\prime}\right) .^{1 \mathrm{a}, 8}$ The solid angles $(\varphi$, the summation of the three bond angles) $)^{3 \mathrm{c}, \mathrm{d}, \mathrm{g}}$ around the pyramidal alkoxo oxygen are $332.7^{\circ}$ for $\mathbf{1}$ and $335.4^{\circ}$ (I) $/ 333.8^{\circ}$ (II) for 2 . In the case of dihydroxo-bridged dicopper(II) complexes, it has been argued that $E\left(\mathrm{~d}_{\mathrm{a}}{ }^{\prime}\right)$ may become less than $E\left(\mathrm{~d}_{\mathrm{s}}{ }^{\prime}\right)$ if $\delta$ is smaller than $130^{\circ} .{ }^{\text {lc }}$ Following the same argument (since $\delta$ is ca. $115^{\circ}$ and $\varphi$ is ca. $\left.334^{\circ}\right), E\left(\mathrm{~d}_{\mathrm{a}}{ }^{\prime}\right)$ should be expected to be less than $E\left(\mathrm{~d}_{\mathrm{s}}{ }^{\prime}\right)$ for $\mathbf{1}$ and $\mathbf{2}$. Therefore, it seems that the energy of the antisymmetric combination becomes lower than that of the symmetric combination due to the first perturbation and increases due to the second perturbation (orbital complementarity) to achieve the accidental degeneracy. If it is argued that the pyramidal disposition of the alkoxo oxygen is the sole factor responsible for the observed ferromagnetism, in that case, the overlap of the 7-azaindolate moiety with the magnetic orbital has to be neglected. This, however, does not appear to be a logical proposition.

To conclude, in addition to be a new type of heterobridged compounds, $\mathbf{1}$ and $\mathbf{2}$ are the first examples where the superexchange is ferromagnetic despite the orbital complementarity. ${ }^{9}$

Acknowledgment. Financial support from the National Science Council, Taiwan (Grant NSC-90-2113-M-032-020), and Department of Science and Technology, Government of India (SR/S1/IC-27/2002), is gratefully acknowledged. S.M. is grateful to Prof. K. Wieghardt for helpful discussion.

Supporting Information Available: Crystallographic data of $\mathbf{1}$ and $\mathbf{2}$ in CIF formats and the ORTEP of $\mathbf{2}$ with selected bond lengths and angles. This material is available free of charge via the Internet at http://pubs.acs.org.

IC035322T

(8) (a) Bertrand, J. A.; Kirkwood, C. E. Inorg. Chim. Acta 1972, 6, 248. (b) Bencini, A.; Gatteschi, D. Inorg. Chim. Acta 1978, 31, 11.

(9) Weak ferromagnetism in $\mu$-alkoxo/hydroxo- $\mu$-carboxylato compounds arises due to orbital countercomplementarity (carboxylate HOMO is symmetric (refs $3 \mathrm{c}$, d, and k)). 